\title{
Physiological and Ecological Analyses of Shade Tolerance of Plants 2. Growth of Dark-treated Green-gram under Varying Light Intensities*
}

\author{
by Masami Monsi**, Hideo IWAKI**, Susumu KuraISHI, ${ }^{* *}$ \\ Toshiro SAEKI** and Nobuo Nomoto***
}

\section{Received February 11, 1962}

In the hope of analysing the shade tolerance of plants, ${ }^{1-3)}$ we began with the pursuit of the growth of green-gram plants under varying light intensities. The experimental results of these normal series $(\mathrm{N}$ - and $\mathrm{O}$-series) have been reported in a previous paper, ${ }^{4)}$ and some attributes ${ }^{5-9)}$ of the plants in day-matter production, such as net assimilation rate (NAR), leaf area ratio (LAR), and ratio of leaf area to leaf weight $(\bar{F} / F)$, have been discussed in reference to the shade tolerance. It has been confirmed that the ability of plants to make the $\overline{\mathrm{F}} / \mathrm{F}$ ratio high under shade plays a positive role in the shade tolerance.

In parallel with the experiments mentioned above, two other series of experiments were made in the summer of 1955 with the dark-treated green-gram plants that were characterized by the rapid elongation of stems at the cost of leaf growth. Such changes in morphology were attended with increase in the $C / F$ ratio, ${ }^{10)}$ i.e. the ratio in dry weight between photosynthetic system $(F)$ and non-photosynthetic system (C) of a plant. In the present study, it has been primarily intended to elucidate how far such morphological changes or variations of the $\mathrm{C} / \mathrm{F}$ ratio can produce effects on growth in the succeeding stages or on the shade tolerance of the plants.

\section{Material and Methods}

A series of preliminary experiment was made in the summer of 1954 using green-grams (Phaseolus aureus Roxb.), in order to know the degrees of growth depression caused by varying period of dark-treatment of young plants in the early stage. Germinating seeds were planted on August 6 in $15 \mathrm{~cm}$-clay pots, which were divided into five groups. One group was placed under full daylight, and the other four were moved to the dark room immediately after the sowing and were respectively replaced in full daylight after a 2-, 3-, 4-, 5- and 7-day dark period. Fig. 1 shows the growth curves in dry weight of the control plants and the treated. Growth retardation in green-gram plants kept in the dark for 2 or 3 days was not so great, and the plants could recover their growth to the level of the controls within 2 or 3 weeks. While, the marked depression of plant growth was shown in the 4-and, more intensively, 5-day dark-treated plots. Green-gram plants could not survive long even if replaced in full daylight after a 7-day dark-treatment in the germination stage. From these results, it was concluded that 4 days as the period of dark-treatment would be suitable for the present experiments.

* A part of the expense was supported by a Grant in Aid of Scientific Research of the Ministry of Education.

** Department of Botany, Faculty of Science, University of Tokyo, Tokyo, Japan.

*** Biological Institute, Faculty of Arts and Sciences, Ibaraki University, Mito, Japan. 


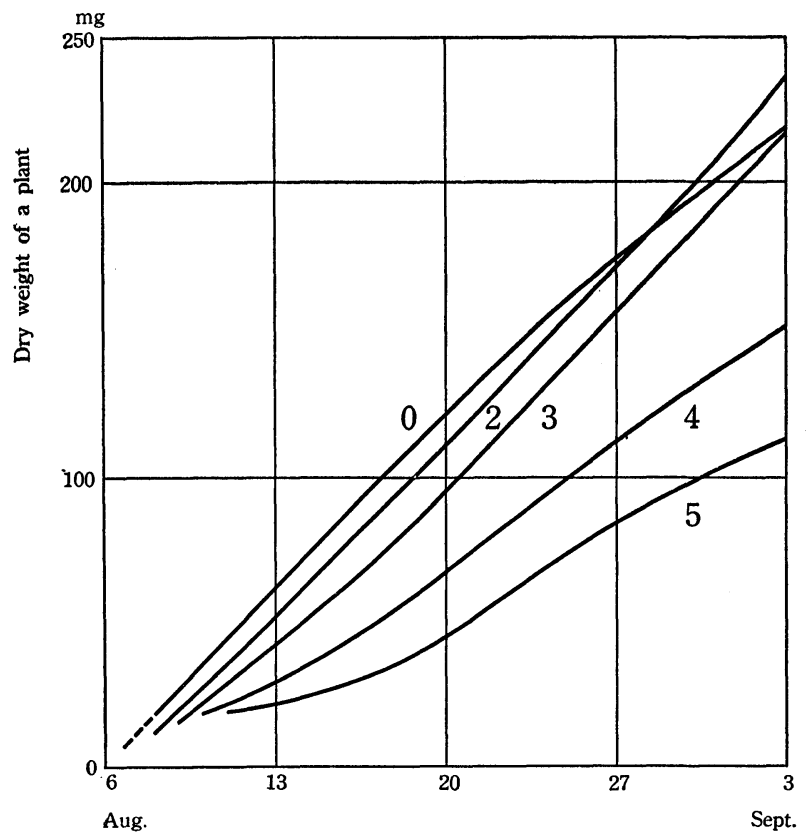

Fig. 1. Growth curves in dry weight of green-gram plants which were grown in full daylight without dark-treatment (0) and after 2-, 3-, 4- and 5-day etiolation.

On August 6, 1955, all seeds were planted in pots and placed in the dark at about $28^{\circ}$. Material plant, size of the pots, and procedures of the sowing were the same as those in the experiment reported in the previous paper of this series. On August 10, the pots of the 4-day dark-treated plants were grouped into five and placed respectively under different light conditions, $100,75,50,30$ and $20 \%$ of full daylight. Each group was again divided into two plots, the one was supplied with Boysen Jensen's nutrient solution periodically, and the other only with tap water (these will be referred to as the $\mathrm{DN}$ - and DO-series). At each sampling 10 plants from two pots ( 5 plants from a pot on and after August 22) were submitted to measurements.

\section{Results and Discussion}

Growth in plant weight: The dark-treated plants showed marked morphological changes. Extremely poor development of the first leaves and abnormal elongation of etiolated stems were characteristics. Table 1 gives numerical information on the initial differences in morphology as well as in the $\mathrm{C} / \mathrm{F}$ ratio between dark-treated (DN and $\mathrm{DO}$ ) and untreated ( $\mathrm{N}$ and $\mathrm{O}$ see the previous paper) plants. The DN and DO plants replaced in $100 \%$ daylight had the higher $\mathrm{C} / \mathrm{F}$ ratio of 7.2 and 7.8 , as compared to 1.2 and 1.1 for the normal $\mathrm{N}$ - and $\mathrm{O}$-plants grown in continuous full sunlight, respectively.

This morphological change at the start should produce a powerful effect on the growth in future. For example, mean initial dry weight on August 10 of a plant except cotyledons was $23 \mathrm{mg}$ in the $\mathrm{N}-100$ plot, $23 \mathrm{mg}$ in the $\mathrm{O}-100$ plot, $19 \mathrm{mg}$ in the DN-100 plot and $22 \mathrm{mg}$ in the DO-100 plot, while the corresponding plant dry weight 
Table 1. Comparison between the dark-treated green-grams (DN-100\% light and DO-100\% light plot) and the untreated ( $\mathrm{N}-100$ and $\mathrm{O}-100)$ of plant dry weight, stem length, leaf area and $\mathrm{C} / \mathrm{F}$ ratio on Aug. 10 (4 days after the sowing) and Sept. 14 (40 days after the sowing), 1955. Cotyl: cotyledon, hyp: hypocotyl, ep: epicotyl. N: supplied with nutrient solution,

O: grown with tap water.

\begin{tabular}{|c|c|c|c|c|c|c|c|c|c|c|}
\hline Aug. 10 & \multicolumn{5}{|c|}{ dry weignt in $\mathrm{mg}$} & \multicolumn{3}{|c|}{ stem length in $\mathrm{cm}$} & \multirow{2}{*}{$\begin{array}{c}\text { leaf } \\
\text { area } \\
\text { in } \mathrm{cm}^{2}\end{array}$} & \multirow{2}{*}{$\begin{array}{l}\mathrm{C} / \mathrm{F} \text { ratio } \\
\text { except } \\
\text { cotyl. }\end{array}$} \\
\hline Series & root & stem & leaf & cotyl. & total & hyp. & ep. & total & & \\
\hline $\mathrm{N}-100$ & 3.9 & 8.7 & 10.7 & 5.7 & 29.0 & 4.6 & 1.7 & 6.3 & 4.7 & 1.2 \\
\hline O-100 & 4.3 & 7.8 & 11.2 & 4.7 & 28.0 & 4.4 & 1.6 & 6.0 & 4.6 & 1.1 \\
\hline DN-100 & 2.5 & 14.5 & 2.4 & 2.4 & 21.8 & 16.3 & 3.5 & 19.8 & 0.9 & 7.2 \\
\hline DO-100 & 2.7 & 16.8 & 2.5 & 2.4 & 24.4 & 16.1 & 3.6 & 19.7 & 0.9 & 7.8 \\
\hline Sept. 14 & \multicolumn{5}{|c|}{ dry weight in $\mathrm{mg}$} & \multicolumn{3}{|c|}{ stem length in $\mathrm{cm}$} & & $\mathrm{C} / \mathrm{F}$ ratio \\
\hline Series & root & stem & leaf & cotyl & total & hyp. & ep. & total & & \\
\hline N-100 & 66.7 & 127.6 & 190.5 & - & 384.8 & 4.4 & 7.4 & 11.8 & 39.8 & 1.0 \\
\hline $0-100$ & 58.0 & 101.7 & 172.7 & - & 332.4 & 4.1 & 6.6 & 10.7 & 36.7 & 0.9 \\
\hline DN-100 & 32.5 & 109.6 & 98.0 & - & 240.1 & 14.8 & 4.8 & 19.6 & 25.7 & 1.5 \\
\hline DO-100 & 41.3 & 119.9 & 104.4 & - & 265.6 & 14.4 & 4.3 & 18.7 & 26.3 & 1.5 \\
\hline
\end{tabular}

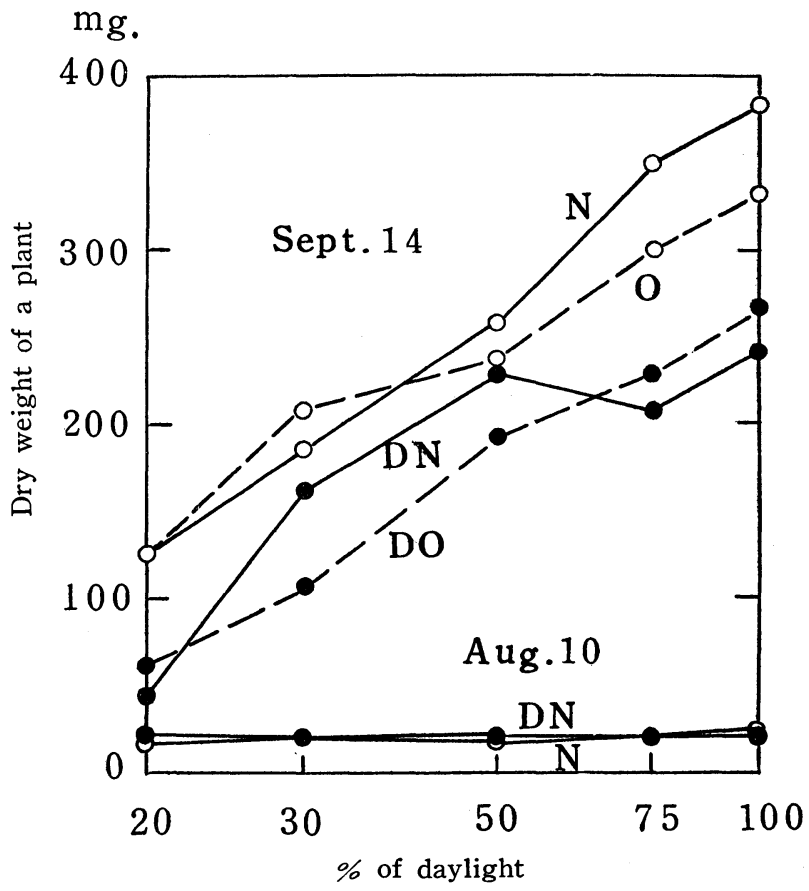

Fig. 2. Mean dry weight of green-gram plants grown under varying light intensities on August 10 and on September 14, 1955. 
at final stage (September 14) was $385,332,240$ and $266 \mathrm{mg}$, respectively (Fig. 2).

Growth curves in dry weight under varying light conditions of the dark-treated plants are set out in Fig. 3-a and $-b$, which represent the results for the DN- and DO-series, respectively. From these figures it is evident that the depressing effect of shading on plant growth is very marked in $20 \%$ light. While, little difference is seen between the plant growth in lighter shade (75 and 50\%) and in full daylight. In the DN-series, for example, dry weight of a plant on September 14 was as average $240 \mathrm{mg}$ in full light, $207 \mathrm{mg}$ in $75 \%$ light, $228 \mathrm{mg}$ in $50 \%$ light, $159 \mathrm{mg}$ in $30 \%$ light, and $43 \mathrm{mg}$ in $20 \%$ light, i.e. in relative values 100:86:95:66:18. The trends of the growth curves in the dark-treated series were very similar to those in the normal series, though the final plant weight (Sept. 14) in the DN-100 plot corresponded to $63 \%$ of that in the $\mathrm{N}-100$ plot.

The effect of nutrient supply was seen only in full light and in lighter shade, but not in the heavily shaded plants (20\%).
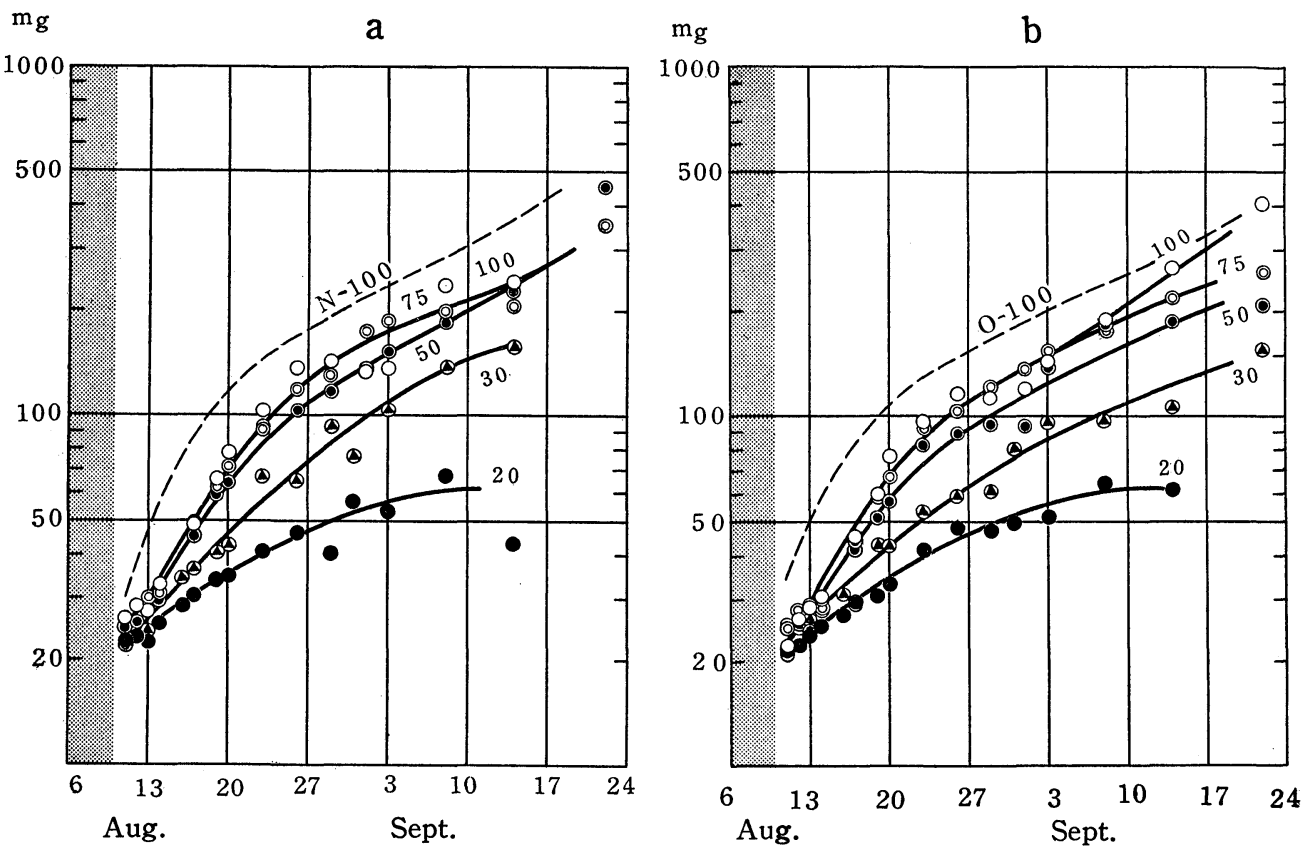

Fig. 3. Growth curves in dry weight of the dark-treated plants of green-gram under 100 , $75,50,30$ and $20 \%$ daylight. Plants of the DN-series (a) were supplied with nutrient solution periodically, while those of the DO-series (b) only with water.

Growth in leaf area: In Fig. 4 are shown the growth curves in leaf area of successive leaves of the dark-treated $(\mathrm{DN}-100)$ and untreated $(\mathrm{N}-100)$ green-grams. On August 10, the treated plants had leaf area (first leaves) of only $0.9 \mathrm{~cm}^{2}$ as compared to $4.7 \mathrm{~cm}^{2}$ in the controls (Table 1). Starting from these values, the first leaves increased their area up to $8.5 \mathrm{~cm}^{2}$ in the DN-series, while $14.5 \mathrm{~cm}^{2}$ in the $\mathrm{N}$-series. Although the final sizes of the first leaves, as well as of the second and third leaves, were markedly smaller in the dark-treated plants than in the untreated plants, the plastochrones of the successive leaves ${ }^{11}$ were nearly the same between both series.

The effect of shading on the total leaf area of dark-treated green-gram is shown in Fig. 5. It is also the case with the dark-treated plants that the growth in total 


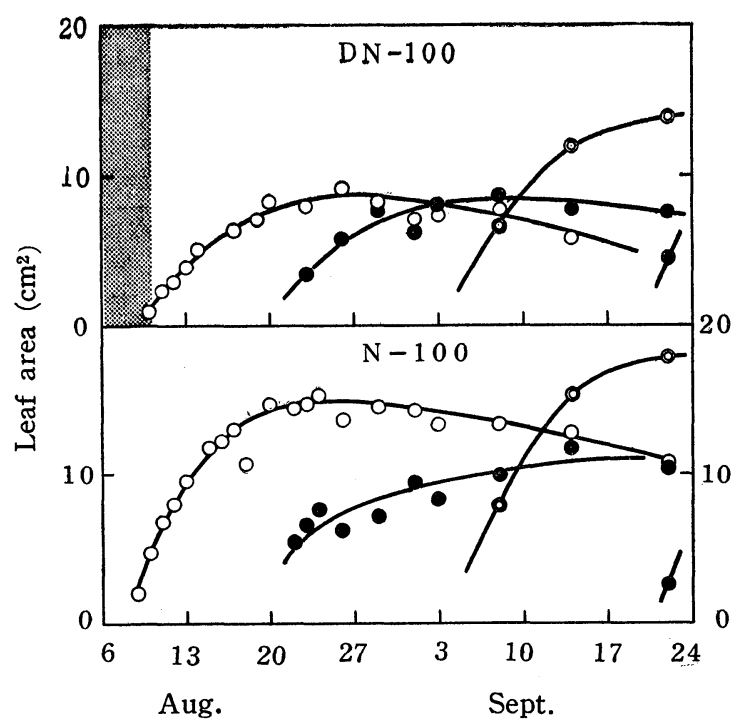

Fig. 4. Growth curves in leaf area of successive leaves of the dark-treated $(\mathrm{DN}-100)$ and untreated $(\mathrm{N}-100)$ greengrams in the earlier stages of the experiment. $\bigcirc$, first leaves; $\bigcirc$, second leaves; $\odot$, third leaves; $\odot$, fourth leaves.

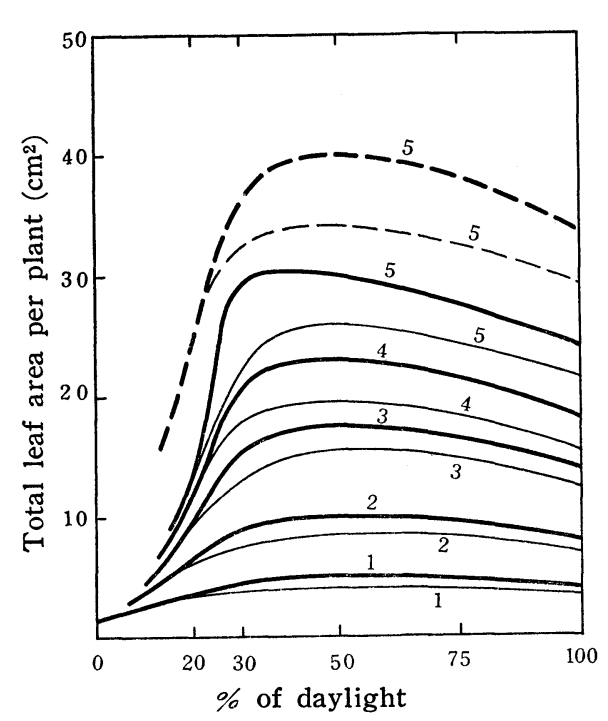

Fig. 5. Leaf area of green-gram plants of the DN-series (thick line) and DOseries (thin line) under varying light intensities. Numerals at the curves indicate number of weeks after the sowing. Thick and thin broken lines represent leaf area of the $\mathrm{N}$ - and $\mathrm{O}$-series, respectively. leaf area showed an optimum in $50 \%$ light rather than in full light, and decreased remarkably in heavy shade, as the normal plants did.

Relative growth rate: The relative growth rates (RGR, $\mathrm{mg} / \mathrm{mg} /$ week) of darktreated green-gram plants were calculated for the period from August 13 to September 10 (Table 2). The trends of the RGR under varying levels of shading in the dark-treated series were the similar as those observed in the normal series (cf. Table 1. in the previous paper). No great difference in the RGR was seen for the period commencing on August 13 among the dark-treated and the normal series, in spite of their marked difference in morphology and in final plant yield. While, detailed examination of the growth curves at the initial stage of the $\mathrm{N}$ and DN-series (Fig. 6) showed a marked retardation of the growth of dark-treated plants. The RGR value of the $\mathrm{DN}-100$ plants calculated for the three days (August 11-13) was low, $0.14 \mathrm{mg} / \mathrm{mg} /$ day $(0.95 \mathrm{mg} / \mathrm{mg} /$ week), as compared with that of the $\mathrm{N}-100$ plants, $0.23 \mathrm{mg} / \mathrm{mg} /$ day $(1.62 \mathrm{mg} / \mathrm{mg} /$ week). 
Table 2. Time trends of relative growth rate ( $R \mathrm{GR}, \mathrm{mg} / \mathrm{mg} / \mathrm{w}$.) of dark-treated green gram plants under varying light intensities.

\begin{tabular}{c|c|cccc}
\hline & $\begin{array}{c}\text { Relative light } \\
\text { intensity }\end{array}$ & Aug. 13-20 & Aug. 20-27 & Aug. 27-Sept. 3 & Sept. 3-10 \\
\hline \multirow{5}{*}{ DN-series } & $100 \%$ & 0.86 & 0.57 & 0.34 & 0.21 \\
& 75 & 0.86 & 0.57 & 0.34 & 0.21 \\
& 50 & 0.83 & 0.52 & 0.34 & 0.27 \\
& 30 & 0.57 & 0.48 & 0.20 & 0.28 \\
& 20 & 0.38 & 0.27 & 0.20 & 0.10 \\
\hline \multirow{5}{*}{ DO-series } & $100 \%$ & 0.85 & 0.48 & 0.31 & 0.34 \\
& 75 & 0.85 & 0.48 & 0.31 & 0.25 \\
& 50 & 0.73 & 0.46 & 0.29 & 0.26 \\
& 30 & 0.47 & 0.38 & 0.31 & 0.25 \\
& 20 & 0.38 & 0.27 & 0.20 & 0.10 \\
\hline
\end{tabular}

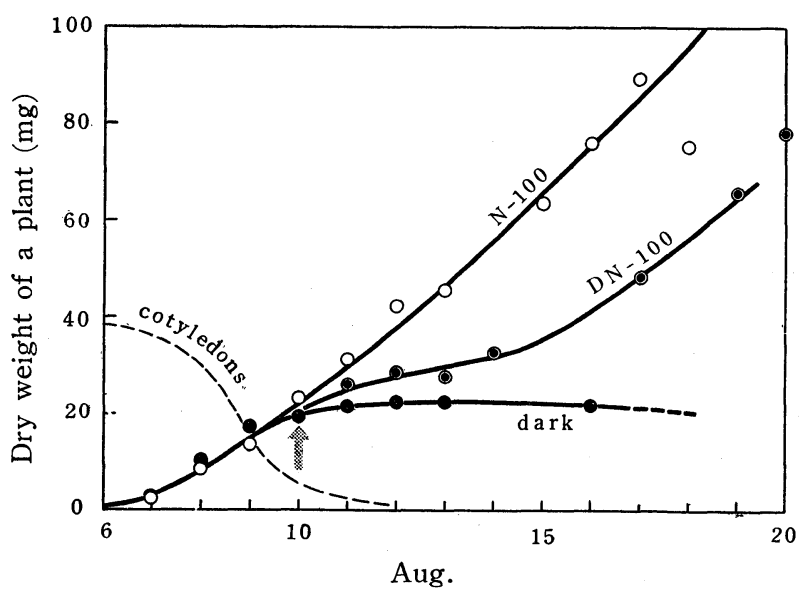

Fig. 6. Detailed growth curves in plant weight (except cotyledons) at the initial stage of the $\mathrm{N}-100$ and $\mathrm{DN}-100$ plants, and of the etiolated plants kept in the dark. Arrow shows the time of the end of the dark-treatment.

These results lead us to the conclusion that the low plant yields of the DN- and $\mathrm{DO}$ - series compared with those of the $\mathrm{N}$ - and $\mathrm{O}$-series were mainly ascribed to the delay in the growth in a few days following the end of the dark-period.

Net assimilation rate and leaf area ratio: The net assimilation rates (NAR) and the leaf area ratios (LAR) of dark-treated green-gram plants were also calculated for the period from August 13 to September 10 (Table 3 and 4).

A comparison of the NAR between the $\mathrm{N}$ - and DN-series in Fig. 7 shows that the NARs in the early stages (August 13-27) of the dark-treated series, especially in the 100,75 and $50 \%$ light, were higher than those of the normal series. While the JARs in all the plots of the dark series were smaller than those of the normal series. The higher NARs of the $\mathrm{DN}$ - and $\mathrm{DO}$-series were offset by the lower values of the LAR, so the RGR, the product of the NAR and the LAR, in the early stages became almost the same as those in the $\mathrm{N}$ - and $\mathrm{O}$-series. In the later stages (Aug. 
Table 3. Time trends of net assimilation rate $\left(\mathrm{NAR}, \mathrm{mg} / \mathrm{cm}^{2} / \mathrm{w}\right.$.) of dark-treated green.gram plants under varying light intensities.

\begin{tabular}{l|c|cccc}
\hline \hline \multirow{5}{*}{ DN-series } & $\begin{array}{c}\text { Relative light } \\
\text { intensity }\end{array}$ & Aug. 13-20 & Aug. 20-27 & Aug. 27-Sept. 3 & Sept. 3-10 \\
\hline \multirow{5}{*}{} & $100 \%$ & 7.1 & 5.0 & 3.1 & 1.9 \\
& 75 & 6.1 & 4.3 & 2.7 & 1.6 \\
& 50 & 5.0 & 3.3 & 2.2 & 1.8 \\
& 30 & 3.1 & 2.3 & 1.0 & 1.4 \\
\hline \multirow{5}{*}{ DO-series } & 20 & 2.3 & 1.4 & 0.9 & 0.5 \\
& $100 \%$ & 7.7 & 4.4 & 2.9 & 3.3 \\
& 75 & 6.5 & 3.7 & 2.4 & 1.8 \\
& 50 & 5.0 & 2.9 & 1.6 & 1.2 \\
& 30 & 2.9 & 2.0 & 0.9 & 0.5 \\
\hline
\end{tabular}

Table 4. Time trends of leaf area ratio, $\left(\mathrm{LAR}, \mathrm{cm}^{2} / \mathrm{mg}\right)$ of dark-treated green-gram plants under varying light intensities.

\begin{tabular}{c|c|cccc}
\hline \multirow{5}{*}{ DN-series } & $\begin{array}{c}\text { Relative light } \\
\text { intensity }\end{array}$ & Aug. 13-20 & Aug. 20-27 & Aug. 27-Sept. 3 & Sept. 3-10 \\
\hline \multirow{5}{*}{ DO-series } & $100 \%$ & 0.12 & 0.11 & 0.11 & 0.11 \\
& 75 & 0.14 & 0.13 & 0.13 & 0.13 \\
& 50 & 0.17 & 0.16 & 0.16 & 0.15 \\
& 30 & 0.19 & 0.20 & 0.20 & 0.20 \\
& 20 & 0.17 & 0.20 & 0.21 & 0.22 \\
\hline & $100 \%$ & 0.11 & 0.11 & 0.11 & 0.10 \\
& 75 & 0.13 & 0.13 & 0.13 & 0.09 \\
& 50 & 0.15 & 0.16 & 0.16 & 0.16 \\
& 30 & 0.16 & 0.19 & 0.21 & 0.21 \\
& 20 & 0.17 & 0.20 & 0.21 & 0.22 \\
\hline
\end{tabular}

27-Sept. 10) of the experiment, however, there was seen little diff srence in the NAR and the LAR among both series.

No effect of the nutrient supply on the RGR, NAR and LAR was observed in the dark-treated green-gram plants (Table 2, 3 and 4).

The ratio of leaf area to leaf weight: In a previous paper ${ }^{4)}$ it was demonstrated that the leaf area/ leaf weight ratio $(\overline{\mathrm{F}} / \mathrm{F})$ of green-gram plants increased markedly with decreasing illumination, and that its high value might be one of the important factors for shade tolerance. The experiments with dark-treated green-grams also gave the same results about $\overline{\mathrm{F}} / \mathrm{F}$ ratio as those with the normal plants. For example, the ratios of the $\mathrm{DN}$-series on August 17 were $0.42,0.48,0.54,0.63$ and $0.66 \mathrm{~cm}^{2} / \mathrm{mg}$, which closely resembled the value of $0.31,0.46,0.50,0.67$ and $0.69 \mathrm{~cm}^{2} / \mathrm{mg}$ of the $\mathrm{N}$-series, for $100,75,50,30$ and $20 \%$-light plots, respectively. No difference in the $\overline{\mathrm{F}} / \mathrm{F}$ ratio was also seen between the $\mathrm{DN}$ - and DO-series (Table 5). Hence it can be concluded that the $\overline{\mathrm{F}} / \mathrm{F}$ ratio is affected neither by nutrition level nor by initial dark treatment, but dependent on the shading level. 


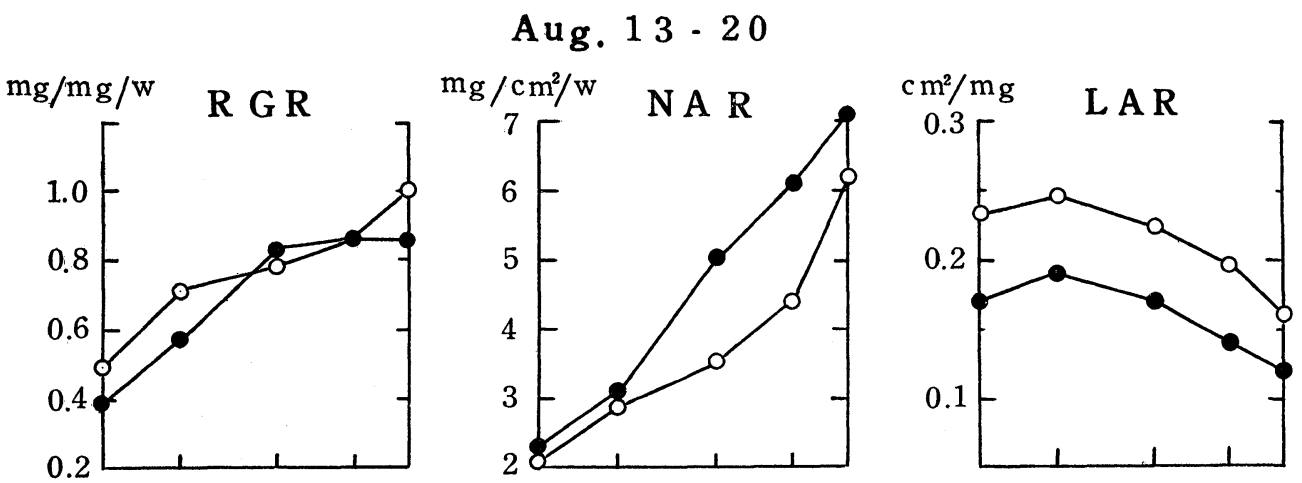

Aug. 27 - Sept. 3
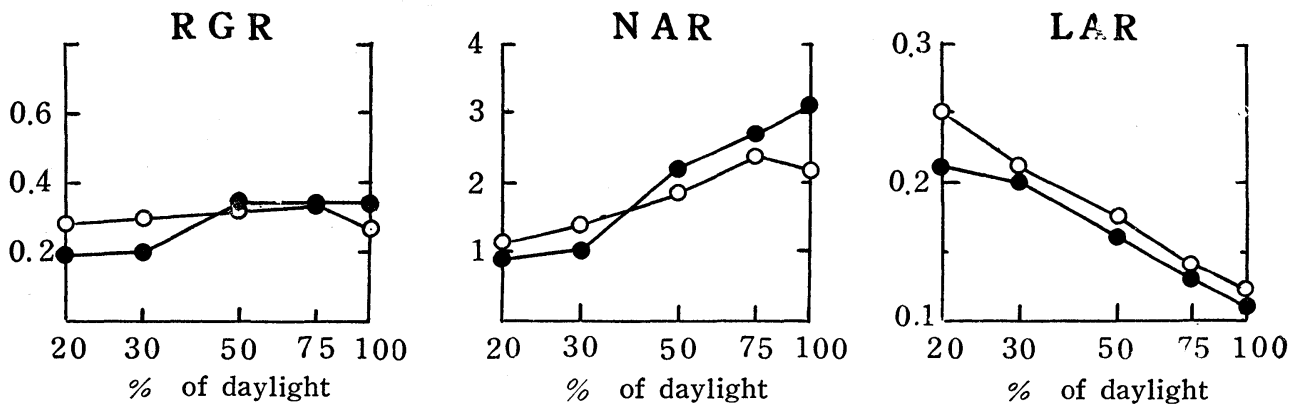

Fig. 7. Comparisons of relative growth rate (RGR), net assimilation rate (NAR) and leaf area ratio (LAR) between the $\mathrm{N}-100(\bigcirc)$ and the $\mathrm{DN}-100$ (O) plot at the early (Aug. 13-20) and the late stage (Aug. 27-Sept. 3) of the experiment.

Table 5. Effect of light intensity on leaf area/leaf weight ratio $\left(\overline{\mathrm{F}} / \mathrm{F}, \mathrm{cm}^{2} / \mathrm{mg}\right)$ of dark-treated green-gram plants.

\begin{tabular}{c|c|ccccc}
\hline \hline \multirow{2}{*}{ Date } & \multirow{2}{*}{ Series } & \multicolumn{5}{|c}{ Relative light intensity } \\
& & $100 \%$ & $75 \%$ & $50 \%$ & $30 \%$ & $20 \%$ \\
\hline \multirow{2}{*}{ Aug. 17 } & DN & 0.42 & 0.48 & 0.54 & 0.63 & 0.66 \\
& DO & 0.39 & 0.49 & 0.54 & 0.65 & 0.65 \\
\hline \multirow{2}{*}{ Sept. 8 } & DN & 0.24 & 0.32 & 0.38 & 0.54 & 0.55 \\
& DO & 0.26 & 0.29 & 0.40 & 0.49 & 0.60 \\
\hline
\end{tabular}

$C / F$ ratio: According to Iwaki ${ }^{12)}$, in buckwheat the $\mathrm{C} / \mathrm{F}$ ratio increased consistently with the development of the plants, while in the normally grown greengrams it kept almost a constant level throughout the developmental period. Fig. 8 shows the time trends of the $\mathrm{C} / \mathrm{F}$ ratio for green-grams in full light of the normal series $(\mathrm{N}$ and $\mathrm{O})$ and the dark-treated series ( $\mathrm{DN}$ and $\mathrm{DO})$. The $\mathrm{C} / \mathrm{F}$ ratio of about 1.0-1.5 was maintained in the former throughout the experiment, while in the darktreated the case was quite different. Here the high $\mathrm{C} / \mathrm{F}$ ratio of 7.2 or of 7.8 at the start decreased rapidly to a half value in a day or two after the end of the darktreatment, and then declined gradually to approach the normal plant's level late 


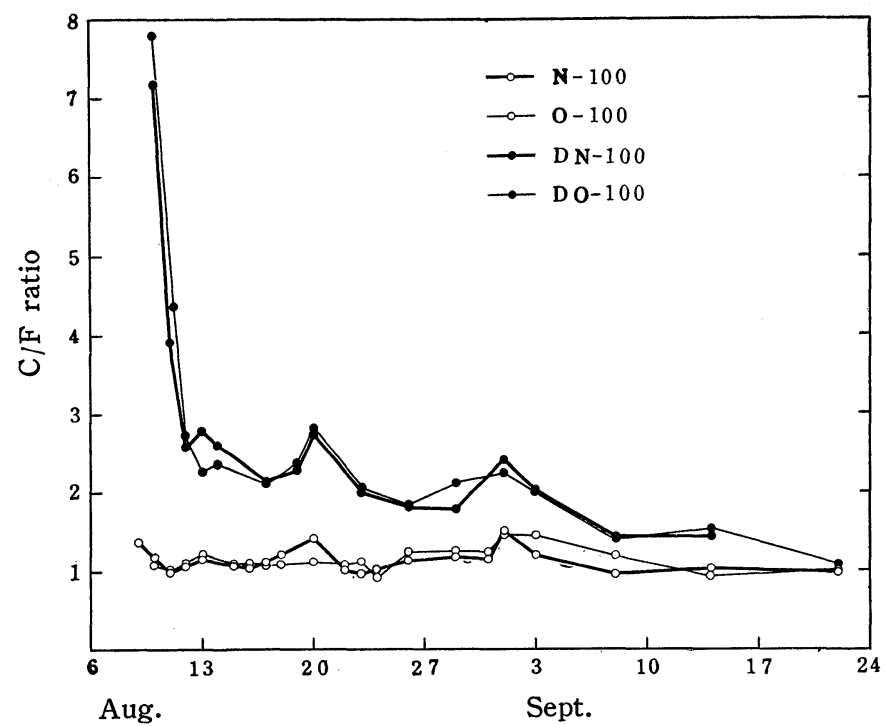

Fig. 8. Time trends of the $\mathrm{C} / \mathrm{F}$ ratio for green-grams in full light of the normal series ( $\mathrm{N}$ and $\mathrm{O}$ ) and the dark-treated series (DN and DO).

in September. Thus it may be assumed that the green-grams have a regulatory ability to adjust the abnormal $\mathrm{C} / \mathrm{F}$ ratio modified by the dark-treatment into the value of normal plants in a given environment.

As mentioned above, the RGR in the dark-treated plants was in fact lower than that in the normal plants for the initial three days, but soon it became the same as that of the latter. Such results correspond to the time trend in the $\mathrm{C} / \mathrm{F}$ ratio, because the high $\mathrm{C} / \mathrm{F}$ ratio corresponds to the low $\mathrm{RGR}$, and vice versa. Since the high $\mathrm{C} / \mathrm{F}$ ratio lowered the NAR and consequently the RGR, the results suggest us that the high $\mathrm{C} / \mathrm{F}$ ratio was mainly responsible for the growth retardation or for the low RGR of the dark-treated plants observed in a few days following the dark-period. Further discussions on the significance in shade tolerance of the different $\mathrm{C} / \mathrm{F}$ ratio will be made in the succeeding paper.

\section{Summary}

Four day etiolated green-gram plants, of which stems elongated enormously at the cost of leaf growth, were grown under varying light intensity $(100,75,50,30$ and $20 \%$ of daylight), and their growth response to the shading was determined and compared with that of untreated green-gram plants.

1. The trends of growth, in dry weight as well as in leaf area, of the darktreated $\mathrm{DN}$ - and $\mathrm{DO}$-series were similar to those of the untreated $\mathrm{N}$ - and $\mathrm{O}$-series. But the final values of plant weight or leaf area were markedly small in the dark. treated as compared with those of the untreated.

2. The relations of the relative growth rate (RGR), the net assimilation rate (NAR) and the leaf area ratio (LAR) to the varying light intensity showed in the dark treated plants also the trends similar to those of the untreated.

3. The NARs in the earlier stages (Aug. 13-27) were much higher in the dark- 
treated series (especially in the 100, 75 and 50\% plot) than those in the untreated series, while the LARs of the former were smaller in all the plots, and consequently the RGRs were scarcely affected by the dark-treatment. In the later stages, however, no difference in these three measures could be observed between the two series.

4. In the initial three days (Aug. 11-13) the RGR of the DN-100 plants was low, $0.14 \mathrm{mg} / \mathrm{mg} /$ day, as compared to $0.23 \mathrm{mg} / \mathrm{mg} /$ day of the $\mathrm{N}-100$. Such low RGR may bring about the low final plant weight of the $\mathrm{DN}$ - and DO-plants.

5. The leaf area/leaf weight ratio $(\overline{\mathrm{F}} / \mathrm{F})$ of the $\mathrm{DN}-$ and $\mathrm{DO}$-plants increased markedly with decreasing illumination and gave nearly identical results with those of the untreated plants.

6. The $\mathrm{N}$ - and $\mathrm{O}$-plants maintained the $\mathrm{C} / \mathrm{F}$ ratio, the ratio of the non-photosynthetic to the photosynthetic system, of 1.0-1.5 throughout the whole experimental period, while the DN- and DO-plants, placed in full daylight after 4 day dark treatment, dropped rapidly $\mathrm{C} / \mathrm{F}$ ratio of $7-8$ at first and then slowly, it approaching to a level of 1.0. The high $\mathrm{C} / \mathrm{F}$ ratio should be largely responsible for the low RGR observed in the initial few days following the dark-period.

\section{References}

1) Dibbern, J. C., Bot. Gaz. 109: 44 (1947). 2) Thorne, G. N., Ann. Bot., N. S. 24: 356 (1960). 3) Manabe, T., J. Jap. For. Soc. 43: 325 (1961). 4) Nomoto, N., Iwaki, H., and Monsi, M., Bot. Mag. Tokyo 74: 386 (1961). 5) Blackman, G. E., and Wilson, G. L., Ann. Bot., N. S. 15: 63 (1951). 6) —, and —, ibid. 15: 373 (1951). 7) —, Black, J. N., and Kemp, A. W., ibid. 19: 527 (1955). 8) — , and Black, J. N., ibid. 23: 51 (1959). 9) Maggs, D. H., ibid. 24: 434 (1960). 10) Iwaki, H., Jap. J. Bot. 16: 210 (1958). 11) Saeki, T., Bot. Mag. Tokyo 74: 70 (1961). 12) Iwaki, H., Jap. J. Bot. 17: 120 (1959).

摘 要

門司正三*·岩城英夫*·倉石 晉*·佐伯敏郎*·野本宣夫**：耐陰性の生理学·生態学的 解析 2. 暗処理をしたヤェナリの種々の強さの光のもとでの生長.

発芽後 4 日間暗所に牧き，茎が異常に伸びたヤエナリの幼植物を，それぞれ $100 ， 75 ， 50,30,20 \% の$ 自然光下に特さ，先の生長を物質生産の面から追跡し，暗処理をしない対照区のヤエナリと比較した。

1. 乾量生長および葉面積生長に対する光の強さの関係は対照区 (前報)の場合とほぼ同様であった。 た だし，実験後期に扮けるヤエナリの個体重，葉面積は，いずれの相対照度のもとでも，瞕処理区の方が対 照区より明らかに小さかった。

2. 瞕処理をしたヤエナリの相対生長率 (RGR), 純同化率 (NAR), 葉面積比 (LAR) と光の強さとの関 係も，全体として，前報で報告した対照区の場合と同じょうな傾向を示した。

実験初期 (8 月 13 日〜27 日) の NAR（特に 100, 75, 50\% 光下）は，処理区の方が対照区よりかなり 大きかったが，LAR は逆に対照区の方が大きく，その結果，RGR にはほとんど暗処理の影響はみられな かった. 実験後期には, NAR, LAR, RGR のいずれにも，両区の羑は注とんどみられなかった。

乙か乙暗処理終了直後の 3 日間 (8 月 11 日〜13 日) についてみると，处理区の RGR は $0.14 \mathrm{mg} / \mathrm{mg}$ /

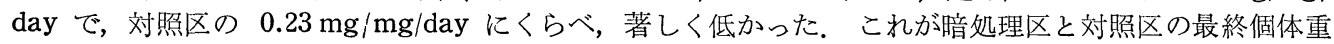
にみられる差の特るな原因と推定された。

3. 瞕処理をしたヤエナリの葉面積/葉重 $(\overline{\mathrm{F}} / \mathrm{F})$ の比は, 光が弱まるほど大きくなり, 対照区と添济同 じ結果を示した.

自然光下で育ったヤェナリの $\mathrm{C} / \mathrm{F}$ 比は，実験期間をつうじて，約 1.0 1.5 の值を維持するが，暗処理 をして自然光下にもどしたヤエナリの $\mathrm{C} / \mathrm{F}$ は, 処理終了直後の約 7 8 の高い值から, 最初は急激に, ついで徐々に低下し，次第に対照区の值に近づいた。暗処理直後にみられる低いRGR の原因の一つは, この高い $\mathrm{C} / \mathrm{F}$ 比にあると推定された. (*東京大学理学部植物学教室, ** 茨城大学文理学部生物学教室) 